\title{
THOUGHTS ABOUT A MULTINATIONAL JUDGMENTS CONVENTION: A REACTION TO THE VON MEHREN REPORT
}

\author{
ANDREAS F. LOWENFELD*
}

I

INTRODUCTION: CREATING A WISH LiST

I am much intrigued by Arthur von Mehren's paper setting out a call for a Hague Judgments Convention. ${ }^{1}$ I think his proposal for a mixed convention, with green, red, and yellow lights for jurisdiction (or black, white, and shades of gray, if you prefer) is quite ingenious. I like making law-which is why I enjoyed being a Reporter for the Foreign Relations Restatement and why I envy Professor von Mehren his role as prospective drafter of the multilateral judgments convention. For political or negotiating reasons, being a member of the United States delegation, he carefully avoids saying what such a convention should provide. I can well understand that he does not want his proposal to place the item on the agenda of the Hague Conference shot down by someone who does not like a particular provision that might be contained in such a convention. Clearly, as an official U.S. spokesman, Professor von Mehren does not want to negotiate the merits of a multilateral judgments convention before agreement has been reached on the shape of the table.

No such constraints apply to me. I am not a spokesman for the United States, nor a member of a delegation, and I cannot imagine that anyone other than my own self would be embarrassed by what I say. Whether the initiative led by Peter Pfund and Arthur von Mehren is worthwhile, however, will depend a good deal on what is said or written at the table, once agreement is reached on its shape. I propose, therefore, to set out here what I think a sound convention on the recognition and enforcement of judgments should contain. My thoughts are the product in part of experience with recognition of judgments in both directions-that is, U.S. judgments abroad and foreign judgments in the United States-in part on experience with the U.N. Convention on the Recognition and Enforcement of Foreign Arbitral Awards (the New York

\footnotetext{
Copyright 191994 by Law and Contemporary Problems

* Herbert and Rose Rubin Professor of International Law, New York University School of Law.

1. Arthur T. von Mehren, Recognition and Enforcement of Foreign Judgments: A New Approach for the Hague Conference?, 57 LAW \& CONTEMP. ProBS. 289 (Summer 1994).
} 
Convention), ${ }^{2}$ and in part on my review of the experience with recognition of judgments in the United States and under the Brussels Convention. ${ }^{3}$

It is important to point out that negotiation between the United States and other states in the Hague Conference is quite different from negotiation among the European states-including the United Kingdom. If anyone doubts this, witness the problems that have arisen in respect to the Hague Evidence Convention, ${ }^{4}$ as well as in the earlier negotiations looking to a bilateral judgments convention between the United States and the United Kingdom. ${ }^{5}$ Litigation in the United States means jury trials, expansive discovery, contingent fees; it means treble damages, punitive damages, and massive damage awards labeled compensatory but elsewhere perceived as going too far-notably for pain and suffering. ${ }^{6}$ But it also means access to the most open market of any major country, careful attention to procedural fairness, and, I submit, a country more hospitable to foreigners and "foreignness" than any country I know of. All of this, I think, must be understood when we contemplate a convention concerning recognition and enforcement of judgments.

I do not suggest that each of the provisions I propose is essential, or that each of the provisions I oppose would be a deal-breaker. My theme is neither a white list nor a black list, but a wish list. I think my wish list is reasonable, and consistent with a position that favors an end to litigation and obedience to judgments. I believe that with skillful negotiation, many, if not all, of the elements on my wish list may be attainable. If that belief turns out to be wrong, I doubt that the effort to achieve a judgments convention is justified.

\section{II}

\section{THE Substantive AsPECTS}

I would divide my wish list in two-roughly speaking substantive and procedural aspects, although in the context of recognition of judgments, these two categories are more overlapping than mutually exclusive. I begin with what I call substantive issues.

2. Convention on the Recognition and Enforcement of Foreign Arbitral Awards, done at New York June 10, 1958, 21 U.S.T. 2517, T.I.A.S. No. 6997, 330 U.N.T.S. 3 (entered into force June 7, 1959; for the United States Dec. 29, 1970).

3. Convention of 27 September 1968 on Jurisdiction and the Enforcement of Judgments in Civil and Commercial Matters, O.J. 1978, L304/77, Cmnd. 7395 as amended, 33 EC O.J. C 189 (July 28, 1990) [hereinafter EEC Convention].

4. Convention on the Taking of Evidence Abroad in Civil or Commercial Matters, opened for signature Mar. 18, 1970, art. 2, 23 U.S.T. 2555, 847 U.N.T.S. 231 (entered into force Oct. 7, 1972).

5. See Proposed Convention between the United Kingdom and the United States for the Reciprocal Recognition and Enforcement of Judgments in Civil Matters, Cmnd. 6771 (1977), reprinted in 16 I.L.M. 71 (1977). Negotiations on this Convention were abandoned in the late 1970s.

6. Pain and suffering, or equivalent concepts, are known in many jurisdictions, for example, Schmerzensgeld in Germany and dommages morales in France, but they rarely reach the dimensions common in U.S. judgments. 


\section{A. The Overriding Principle}

If the procedures in the rendering court were fair-as should be subject of at least a presumption among states willing to enter into a judgments convention-the judgment should be recognized and enforced. There is no room, in my view, for the kind of judgment recently rendered by a lower court in New York, refusing recognition to a libel judgment rendered by an English court, on the ground that the English court did not honor the values embodied in the First Amendment to the United States Constitution. ${ }^{7}$ Nor, in my submission, is there any room for the kind of judgment rendered recently by a lower court in Berlin, refusing recognition and enforcement to a product liability judgment rendered by a Massachusetts court, on the ground that the jury in rendering its verdict did not explain the causal relationship between the alleged defect of the defendant's machine and the plaintiff's injury. ${ }^{8}$ Here incidentally, is a perfect illustration of interaction between substance and procedure: no American would expect a jury to give a reasoned explanation of its decision. ${ }^{9}$ But a demand for a reasoned decision would in effect exclude judgments based on jury verdicts from international recognition.

\section{B. Public Policy}

I suppose it is generally accepted that the law of recognition of judgments-whether expressed in statute, treaty, judicial decision, or even a Restatement-must leave some safety valve for violation of public policy or ordre public. I think a convention among states with basically shared values should contain a definition of public policy that is very narrowly drawn. I like the statement made by Judge J. Joseph Smith for the United States Court of Appeals for the Second Circuit in connection with the New York Arbitration Convention:

Enforcement of foreign arbitral awards [read foreign judgments] may be denied on [the] basis [of public policy] only where enforcement would violate the forum state's most basic notions of morality and justice..$^{10}$

Public policy should not, as the Second Circuit also wrote, become a major loophole in the Convention's mechanism for enforcement. ${ }^{11}$ Neither a difference concerning jurisdiction of the rendering court nor a difference

7. Bachchan v. India Abroad Publications, Inc., 585 N.Y.S.2d 661 (Sup. Ct. 1992). Following the decision, the parties reached a settlement, and the decision was not appealed.

8. Landergericht Berlin, Judgment of June 13, 1989 (Solimene v. B. Grauel \& Co.), 1989 Recht der internationalen Wirtschaft [RIW] 988 (F.R.G.), translated and reproduced in ANDREAS F. LOWENFELD, INTERNATIONAL LITIGATION AND ARBITRATION 440 (1993). This case, too, was settled prior to decision on appeal, and thus should be regarded as evidence of attitude, rather than as authority.

9. In fact, in Solimene, the jury answered six special questions. See Solimene v. B. Grauel \& Co., 507 N.E.2d 662 (Mass. 1987).

10. Parsons \& Whittemore Overseas Co. v. Société Générale de l'Industrie du Papier (RAKTA), 508 F.2d 969, 974 (2d Cir. 1974).

11. Id. 
concerning damages should be permitted to slip by under the cover of public policy or ordre public. ${ }^{12}$

\section{Double Cause of Action}

We are used to the double criminality rule in international extradition treaties, ${ }^{13}$ although I have never found it persuasive. If a fugitive from country $A$, credibly accused by country A's authorities of a serious crime under A's law, is found in country $B, I$ believe $B$ should be required to return him or her to $A$, provided, of course, that the normal safeguards in the extradition treaty are complied with. I do not think it should matter whether the crime charged in A is also a crime, or also a felony, in $\mathrm{B}^{{ }^{14}}$

One can debate this position, although not here. I bring it up only to suggest that the issue is much easier in the context of civil litigation. A claim in a civil action, as Professor Austin Scott, a reporter to the first Restatement of Judgments, taught us forty years ago, is merged into a judgment if the judgment is rendered in favor of the plaintiff. ${ }^{15}$ The operative part of a judgment (postponing questions of injunctions and orders for specific performance) simply states that the defendant shall pay to the plaintiff the sum of $X$ dollars, marks, yen, or whatever. Except in those few instances that fit through the narrow opening of a public policy defense, I do not believe that a court in which recognition and enforcement are sought should compare the underlying action in the first forum (F-1) with the law of the second forum (F-2). Thus, I approve of the judgment of the New York court recognizing and enforcing a Quebec judgment rendered for the plaintiff in an action for alienation of affection and criminal conversation, although such actions had been abolished in New York twenty years earlier as contrary to New York's public policy. ${ }^{16}$ Similarly, I approve the judgment of the Manitoba Court of Queen's Bench enforcing the judgment of a Hawaiian court for a deficiency under a mortgage, although under Manitoba law a mortgagee that has foreclosed on a mortgage has no further rights against the mortgagor. ${ }^{17}$ I would hope a modern judgments convention would make this point clear and express.

12. Compare EEC Convention on Jurisdiction and the Enforcement of Judgments in Civil and Commercial Matters art. 28.

13. See, e.g., Extradition Treaty, June 8, 1972, U.S.-U.K., art. III, 28 U.S.T. 227; Treaty of Extradition between the United States and Canada, Dec. 3, 1971, art. 2, 27 U.S.T. 983.

14. I hasten to add I am not suggesting abandonment or exclusion of purely political crimes, such as lesé majesté, seditious libel, and the like. I include exclusion of political offenses in the normal safeguards referred to in the previous sentence. (1982).

15. See RESTATEMENT OF JUDGMENTS $\$ 47$ (1942); RESTATEMENT (SECOND) OF JUDGMENTS $§ 18$

16. Neporany v. Kir, 5 A.D.2d 438, 173 N.Y.S.2d 146 (N.Y. App. Div. 1958) (treating a foreign country judgment for this purpose in the same way as a sister-state judgment). Compare Parker v. Hoefer, 142 N.E.2d 194 (N.Y. 1957).

17. Honolulu Federat Savings \& Loan Ass'n. v. Robinson, 64 D.L.R.4th 551 (Man. Q.B. 1989). 


\section{Damages}

1. No doubt, the level and form of the award of damages are the most controversial substantive aspect of any discussion of recognition and enforcement of foreign judgments. I am prepared to accept a compromise solution that breaks somewhat with the thrust of my presentation thus far. I would be prepared to agree expressly that punitive damages (properly defined) be excluded from international recognition and enforcement, provided it was clearly stated that a judgment awarding both punitive and compensatory damages could be upheld as to the compensatory elements. I am pleased to see that the German Supreme Court has recently so held, in a suit on a judgment rendered by a California court arising out of a claim of sexual molestation of a minor. ${ }^{18}$ I am less clear about multiple damages-for instance treble damages in U.S. antitrust cases, but I would be prepared to concede that the doubled or trebled amount need not be awarded in the second forum-again provided the compensatory element of the judgment is not deprived of its entitlement to recognition and enforcement.

2. When Professor von Mehren negotiated with the British in the 1970's, the United Kingdom had not yet adopted the Protection of Trading Interests Act $1980,{ }^{19}$ and thus we had not heard about the infamous "claw-back clause." That clause, you will recall, is designed to enable a defendant who has paid treble damages pursuant to the judgment of a U.S. court to recover in a British court the amount that exceeds the compensatory element of the judgment. So far as I know, that clause has not yet been applied in an actual case; it has no place among parties to a judgments convention. Even if the rest of the Protection of Trading Interests Act remains in effect-a subject on which I have previously expressed my views ${ }^{20}$-section 6 (and corresponding provisions in the laws of Canada ${ }^{21}$ and Australia $^{22}$ ) have to go.

3. I believe that a judgment that includes lawyers' fees-whether by virtue of a contingent fee arrangement under American law or by virtue of an award for costs under the law of England, Germany, and many other states-should be enforced like any other judgment, in other words, with no examination of the composition of the damages. ${ }^{23}$ Several recent cases persuade me that the point

18. Decision of Bundesgerichtshof, IX Civ. Sen. June 4, 1992, 118 BGHZ 312. For a detailed discussion of this case in English, see Joachim Zekoll, The Enforceability of American Money Judgments Abroad: A Landmark Decision by the German Federal Court of Justice, 30 CoLUM. J. TRANSNAT'L L. 641 (1992).

19. United Kingdom Laws 1980 , c. 11, 47 Halsbury's Stat. 454 (4th ed. 1988).

20. Andreas F. Lowenfeld, Sovereignty, Jurisdiction, and Reasonableness: A Reply to A.V. Lowe, 75 AM. J. INT'L L. 629 (1981).

21. Foreign Extraterritorial Measures Act, R.S.C. ch. F-29, $\$ 9$ (1985) (Can.).

22. Foreign Proceedings (Excess of Jurisdiction) Act 1984, No. 3 of 1984, $\$ 10$ (Austl.).

23. A reader may be surprised that I bring this issue up at all. But it was one of the grounds of resistance raised in the well-known U.S. case, Somportex Ltd. v. Philadelphia Chewing Gum Corp., 453 
is worth specifying in a convention, although agreement should not be too difficult to obtain. ${ }^{24}$

4. When the negotiation of a bilateral judgments convention between the United States and the United Kingdom was going badly in 1978 because of resistance by the British insurance industry, an attempt to rescue the project focused on proposed Article 8A, which would have read as follows:

Where the respondent establishes that the amount awarded by the court of origin is greatly in excess of the amount, including costs, that would have been awarded on the basis of the findings of law and fact established in the court of origin if the assessment of that amount had been a matter for the court addressed, the court may, to the extent then permitted by the law generally applicable in that court to the recognition and enforcement of foreign judgments, recognize and enforce the judgment in a lesser amount. $^{25}$

The object of the proposal, evidently, was to bridge the gap between the norms of damage awards in the United Kingdom and the perceived excesses of such awards in the United States in personal injury and wrongful death cases. The court asked to recognize and enforce a judgment-presumably British-would be bound to accept the findings of liability on which the judgment was based. It could not, for instance, reexamine the proportion of the injury attributed to the plaintiff or the causal relation between the alleged defect of a product and the injury to the plaintiff. But as to damages, it could apply F-2 standards to cut down the amount that could be collected in F-2.

I do not recall who first came up with this proposal, which intrigued me when I first heard of it. On reflection, however, I believe the idea should be discarded permanently. Quite apart from the practical problems of having a court-or perhaps a special master-in F-2 reviewing the trial record in F-1 (imagine what would happen if the language of F-2 were not English), the notion that a review of the size of an award can be separated from révision au fond in general is unsound in principle. Révision au fond is contrary to the whole rationale of recognition and enforcement of judgments. It may well be that a number of countries will be afraid to sign a judgments convention with the United States, though it seems improbable to me that many manufacturers, transport companies, and insurance companies can take advantage of the American market while insulating themselves from judgments of American

F.2d 435, 443 (3d Cir. 1971), cert. denied, 405 U.S. 1017 (1972), and it also came up in the recent German case cited at note 18 supra, in which the Court of Appeals, having cut down the award for pain and suffering and eliminated the award of punitive damages completely, added $25 \%$ for attorneys' fees to as much of the award as it was prepared to confirm, which it called the recognizable portion of the punitive damage award. The Supreme Court of the Federal Republic reversed the Court of Appeals on this point as well as on the reduction of recovery for pain and suffering.

24. Thus, I disagree with the decision of the United States Court of Appeals for the Second Circuit in Ackerman v. Levine, 788 F.2d 830 (2d Cir. 1986), which applied a "narrower, evidentiary-based public policy" to reduce the judgment of a German court in a suit for legal fees brought by a law firm in Berlin. Id. at 843. Ackerman is different from the cases cited in the preceding note in that legal fees were not ancillary to a damage judgment, but were the entire object of the first action and judgment.

25. As the proposal went back and forth between the U.S. and British delegations and advisers in both states, several differences in the drafting crept in. The thrust of the proposal, however, remained as quoted. 
courts. I want to make clear, also, that what I have said here is not to be regarded as a defense of all aspects of the American legal system, including the level of tort damages. I do not, however, accept the idea of a convention that would give half faith and credit to judgments of courts in the United States, or that would be effective for controversies between merchants but would be inapplicable to judgments in tort.

5. One more point about damages is worth noting. In a number of countries-most notably Germany-damages in tort cases are regularly awarded in the form of periodic rather than lump sum payments. There are advantages and disadvantages to periodic payments, which we know in the United States principally in connection with child and spousal support and workers' compensation. I do not believe, however, that the issue is one for the law of recognition of judgments. I see no good reason why a judgment ordering periodic payments should not be enforced to the same extent as a judgment for a single payment. If some form of trust or escrow needs to be created to secure the judgment creditor's rights, so be it. We should not, however, decline to enforce a judgment on some unsound principle that it is not "final" just because it calls for periodic payments.

\section{III}

\section{The Procedural Aspects}

Thus far I have addressed only what I have called the substantive aspects of a judgments convention-although, as is evident, that term is far from precise. I want now to turn to some procedural aspects of a judgments convention as they appear on my wish list.

\section{A. Jurisdiction: Black, White, and Gray}

It is not necessary to go into detail on the basic principle that only judgments rendered by a court having jurisdiction over the judgment debtor under internationally accepted criteria are entitled to recognition. I have expressed at the outset my agreement with Professor von Mehren's idea of the gray list, though I might draft the proposal somewhat more favorably to recognition, for instance by permitting states to make declarations that judgments rendered on the following bases of jurisdiction will not be recognized, the idea being that courts would not be precluded from recognizing judgments founded on other bases of jurisdiction. ${ }^{26}$

One may discuss which bases of jurisdiction fit into the white as opposed to the gray list and, indeed, whether the gray list needs to be spelled out at all or

26. Compare, e.g., the declarations provided for under Article 10 of the Hague Convention on the Service Abroad of Judicial and Extrajudicial Documents in Civil or Commercial Matters, opened for signature Nov. 15, 1965, art. 2, 20 U.S.T. 361, 658 U.N.T.S. 163, whereby states may announce that they do not accept service by mail or service through judicial officers or other officials without going through the Central Authority. 
is simply an implied repository of jurisdictional bases not otherwise accounted for. For example, one might debate whether "doing business" in a state through a branch or agency subjects a firm to general jurisdiction, as seems to be the majority rule in the United States, ${ }^{27}$ or only to claims arising out of the operations of the branch or agency, as is the rule under the Brussels Convention. ${ }^{28}$ Another example may be jurisdiction over co-defendants, one of whom is domiciled in the forum state but the others are not, as is permitted under the Brussels Convention, ${ }^{29}$ and (with leave of the Court) under English law, ${ }^{30}$ but probably not under U.S. law. ${ }^{31}$ The Brussels Convention, which contains both a black list (Article 3) and a white list (Articles 2 and 5-17), places in neither list the provision of English law permitting jurisdiction on the basis that a contract is "by its terms or by implication governed by English law." ${ }^{32}$ My view is that each of these questions is a marginal one, within a broad international consensus on the proper bases for judicial jurisdiction.

I note that the Conclusions of the Working Group Meeting on Enforcement of Judgments, organized by the Hague Conference to discuss the von Mehren proposal, places "doing business" as a ground of general jurisdiction in the category of "Grounds of Jurisdiction that might be excluded," that is, as a candidate for the black list. ${ }^{33}$ I would prefer to include "doing business" in the category of grounds of jurisdiction that could be, but would not be required to be, recognized, that is, on the gray list. I could imagine some kind of horse trading in the development of a gray list. For instance, the U.S. delegation might give up its insistence on "doing business" as a basis for general jurisdiction, while the Europeans (and others) might accept personal service on the defendant as a basis for general jurisdiction, as recently rejuvenated by the U.S. Supreme Court in the Burnham case. ${ }^{34}$

B. Res Judicata and Jurisdiction

1. What is not so clear is who decides in a given case whether the jurisdictional standard has been met and how often the question may be raised. The Brussels Convention is clear that jurisdictional questions are to be raised

27. See 1 Robert C. CASAd, Jurisdiction In Civil ACtions, § 3.02[2][a] (2d ed. 1991); RESTATEMENT (SECOND) OF CONFLICT OF LAWS $§ 47$ (1971).

28. EEC Convention on Jurisdiction and the Enforcement of Judgments, supra note 3, art. 5(5).

29. Id. art. 6(1).

30. Rules of the Supreme Court [R.S.C.], Order 11, Rule 1(1)(c) (Eng.).

31. See Casad, supra note 27, at $\$ 3.03[1]$; RESTATEMENT (SECOND) OF CONFLICT OF LAws $\S 40$ cmt. $i(1971)$.

32. R.S.C., Order 11, Rule 1(1)(d)(iii). Professor Schlosser, in the official Report on the October 9, 1978 Convention on the Accession of the Kingdom of Denmark, Ireland, and the United Kingdom of Great Britain and Northern Ireland to the Brussels Convention, asserts that jurisdiction on this basis is precluded with respect to persons domiciled in contracting states. 22 O.J. Eur. Comm. (No. C 59) 71, I 87 (Mar. 5, 1979).

33. Hague Conf. Doc. L.c.ON No 2 (93), at II 10 (Jan. 4, 1993).

34. Burnham v. Superior Court, 495 U.S. 604 (1990). 
only once-in an F-1 court. ${ }^{35}$ The United Kingdom Civil Jurisdiction and Judgments Act $1982,{ }^{36}$ with respect to judgments not covered by the Brussels Convention, permits the defendant to challenge the jurisdiction in F-1, and, if he loses and does not participate further in the action, the defendant may challenge the rendering court's jurisdiction again in F-2, that is, in the United Kingdom. ${ }^{37}$ The United States has a middle position, applicable, so far as one can tell, equally to judgments coming under the Full Faith and Credit Clause and to judgments rendered in foreign countries. A defendant may raise a jurisdictional challenge in F-1, or he may default in F-1 and raise the jurisdictional challenge in an enforcement proceeding in $\mathrm{F}-2$, but he cannot do both. ${ }^{38}$ In other words, in the United States, the results of a challenge to jurisdiction in F-1 are binding; in the United Kingdom, they are not. Within the Brussels/Lugano regime, the issue does not really arise, because a court in F-2 generally has no authority at all to examine the jurisdiction of the F-1 court, and in the limited instances when the F-2 court can question the jurisdiction of the F-1 court, the court in which recognition or enforcement is sought is bound by the findings of fact on which the F-1 court based its jurisdiction. ${ }^{39}$

2. My starting point on this question is that a determination of jurisdiction after challenge in F-1 ought to be entitled to recognition, like other parts of the judgment of F-1, and I have made this point in writing in the past. ${ }^{40} \mathrm{I}$ confess, however, that my colleague, Professor Silberman, has been hammering away at me on this issue, and has to some extent created doubts in my mind, though $I$ am far from recantation. A possible compromise, similar to Article 28 of the Brussels Convention, would be to provide that factual determinations made in connection with a jurisdictional challenge in F-1-for instance, whether $\mathrm{X}$, established in F-1, was the agent of the defendant-would be binding, but legal conclusions-for instance, whether a claim was related to, or arose out of, the activities of defendant's branch in F-1-would not be binding in F-2. Of course, the factual/legal distinction is not iron-clad; for example, if the jurisdiction of the rendering court was asserted on the basis of a contract made in F-1 and the defendant denies that a contract was concluded, the determination in F-1 that a contract had been formed may well incorporate both factual and legal conclusions. But if, for instance, the defendant had claimed that the signature on a document was not his but the court in F-1 had determined that the signature was genuine, I do not think the F-2 court should be permitted to reexamine the

35. EEC Convention, supra note 3 , arts. $19,20,27,28,34$.

36. 1982 Laws c.27 (Eng.)

37. Id. \& 33 .

38. See Baldwin v. Iowa State Traveling Men's Assn., 283 U.S. 522 (1931); Somportex Ltd. v. Philadelphia Chewing Gum Corp., 453 F.2d 435 (3d Cir. 1971), cert. denied, 405 U.S. 1017 (1972); Hunt v. BP Exploration Co. (Libya) Ltd., 492 F. Supp 885 (N.D. Tex. 1980) (contra as to foreign country judgment). See also RESTATEMENT (THIRD) OF FOREIGN RELATIONS LAW $\S 482 \mathrm{cmt}$. c and Reporters' Note 3, also $\S 481$ Reporters' Note 3 and cases cited therein (1987).

39. EEC Convention, supra note 3, art. 28, II 2.

40. Andreas F. Lowenfeld, Conflict of Laws English Style, Review Essay on Dicey and Morris on the Conflict of Laws, 11th Edition, 37 AM. J. COMP. L. 353, 361-69 (1989). 
genuineness of the signature. On the other hand, if the court in F-1 had concluded that the document was an acceptance of the plaintiff's offer, thus forming the contract, perhaps the court in F-2 could be permitted to consider the defendant's claim that the document was really a counter-offer and that no contract had come about.

3. As a further compromise, one might expand somewhat the list of steps that a defendant could take in F-1 without being regarded as having submitted to the jurisdiction of the F-1 court. For instance, a motion for a stay of litigation pending arbitration, or a motion to dismiss on grounds of forum non conveniens, need not be regarded as an appearance for purposes of conferring jurisdiction on the F-1 court, at least in the context of recognition pursuant to the convention. ${ }^{41}$ I am not entirely happy with either of these proposed compromises, but if accepting them is the price for being labeled an idealist rather than an idealogue, I would be prepared to go along.

\section{Default Judgments}

In principle, I think that there should be no difference with respect to recognition between judgments rendered in default of appearance by the defendant and judgments rendered after contest. Otherwise, as Dicey and Morris point out, "the clearer the plaintiff's case, the more useless his judgment would be" if the defendant had no assets in the state of the rendering court. ${ }^{42}$ The principle needs some qualification, however. The successful party should be required, if challenged, to prove in F-2 that the defendant was duly served with initiating process (whether in F-1 or elsewhere), that there was sufficient time to prepare a defense, and that no travel restrictions or similar impediments prevented the defendant from appearing in the first forum to mount a defense.

The fact that the opportunity remains in F-1 for the defendant to reopen a default should not be regarded as impairing the finality of the judgment sought to be enforced in F-2, any more than finality is impaired by a pending appeal in F-1. One might consider a provision in a judgments convention to the effect that a judgment rendered by default in F-1 shall not be entitled to recognition in F-2 unless the claimant has established his claim or right to relief by evidence satisfactory to the court in F-1, as contrasted with a judgment simply based (in default of a reply) on the statement of claim by the plaintiff. ${ }^{43}$ One might

41. The example comes from the much debated case of Henry v. Geoprosco Int'l Ltd., [1976] Q.B. 726 (C.A.), and from $\S 33$ of the U.K. Civil Jurisdiction and Judgments Act 1982 (c.27). If the F-1 court held that the parties had not concluded an agreement to arbitrate covering the controversy, and thereafter rendered judgment for plaintiff, when plaintiff sought to enforce the judgment in F-2, defendant could, under this formulation, challenge the judicial jurisdiction of the F-1 court; he could not, however, again interpose the arbitration clause, because the determination that it was not effective or did not cover the controversy would be binding as res judicata.

42. AlBERT V. DICEY \& JOHN H.C. MORRIS, THE CONFLICT OF LAWS 429 (11th ed. Collins, 1987).

43. Compare, e.g., the U.S. Foreign Sovereign Immunities Act $\S 1608$ (d), concerning default judgments against foreign states or state instrumentalities. The British State Immunity Act has no comparable provision. See $\$ 12$. 
consider applying such a rule also to other kinds of default judgments, for instance to judgments entered against a party disobeying an order for discovery. $^{44}$

\section{Injunctions}

1. In general, injunctions issued by one court have not been given much respect by other courts, especially if the other courts are located in different states. The reason may be that injunctions are perceived as requiring continuing judicial supervision, and thus not easily transferable from one state to another. Also, injunctions are often subject to modification, and even if not, they do not fit easily into the definition of a final judgment. Nevertheless, I think the banishment of injunctions from the law of recognition and enforcement of judgments is too broad. It seems to me that in two areas, at least, consideration should be given to including injunctions within a comprehensive judgments convention. When a party is ordered by a court in one state not to dispose of his assets wherever they may be located, as under a Mareva injunction, it seems to me that courts of other states ought to be prepared-if not required-to cooperate.

We recently have seen, for instance, that English courts will, in appropriate cases, restrain parties over whom they have jurisdiction from dealing with any of their assets worldwide. ${ }^{45}$ The injunction is binding on the target of the injunction, who may or may not be a judgment debtor, as well as on banks and other custodians of assets in England when duly notified. ${ }^{46}$ But in order to avoid "exorbitant assertion of extraterritorial jurisdiction over third parties," the Court of Appeal ruled in two cases that the injunction would not apply to third parties outside of England, even when those third parties, such as major British and foreign banks, were present both in England and in foreign countries where they might have held assets of the defendant. ${ }^{47}$ Thus, for instance, if the target of the Mareva injunction had assets in Credit Suisse in Geneva or Citibank in New York, the injunction would not restrain those banks from honoring withdrawal orders issued by the target, even though the two banks had branches in England which had been duly notified of the injunction.

I believe the English courts have stopped at the right place; but if the plaintiff (that is, the person on whose application the Mareva injunction was issued) takes the injunction to the appropriate court in New York or Geneva, I think that court should act to enforce the injunction-that is, it should issue

44. Compare U.S. FED. R. Civ. P. 37(b)(2)(C); U.K. R.S.C., Order 24, Rule 16.

45. See, e.g., Babanaft Int'l Co. S.A. v. Bassatne, [1990] Ch. 13, [1989] 2 W.L.R. 232 (C.A.). For a detailed discussion of this and similar cases, see Lawrence Collins, The Territorial Reach of Mareva Injunctions, 105 L. Q. REV. 262 (1989).

46. See generally Order 29, Rule 1/20-23 in 1 The SuPREMe COURT PraCTICE (1991) (Eng.).

47. See Babanaft, [1990] Ch. 13, [1989] 1 All E.R. (C.A.); Republic of Haiti v. Duvalier, [1990] Q.B. 202, [1989] 2 W.L.R. 261 (C.A.). 
its own injunction on the basis of the F-1 injunction. ${ }^{48}$ I would hope the convention would encourage this result. ${ }^{49}$

2. Similarly, we have recently seen a large number of important international bankruptcies-Alan Bond, Olympia \& York, Maxwell, BCCI-and others less celebrated but not less international in scope. We have seen the spectacle of a court in the United Kingdom enjoining removal of assets of a U.S. company from that country pending adjudication of claims by English creditors, notwithstanding the fact that the company was being reorganized under Chapter 11 of the U.S. Bankruptcy Code, and the fact that the bankruptcy court in New York had issued an order restraining all legal action against the debtor company except in the context of the bankruptcy proceeding. ${ }^{50}$ In the reverse situation, considered but not followed by the English court, a U.S. court ordered release of a vessel arrested in New York by creditors of a company involved in bankruptcy proceedings in Sweden, so that the property could be administered in accordance with the orders of the Swedish court. ${ }^{51}$ I do not know enough about the different solutions to bankruptcy in different countries to have a firm view on how cases such as these should be dealt with, but my instinct is to look to the orders of the court where the principal proceeding takes place. For present purposes, I would urge only that there should not be any presumption that injunctions of foreign courts do not matter or run only in personam. ${ }^{52}$

3. I do not suggest that complicated matters such as Mareva injunctions and transnational bankruptcy be placed on the agenda of a judgments convention right away. But I suggest that the traditional narrow focus of judgments conventions is misplaced-no longer appropriate in an age in which the combination of computers and communication by satellite has made almost instantaneous transfer of funds commonplace, and has rendered the opportunities for fraud more widespread than ever. I would hope that the drafters of a

48. In a third case in this series, Derby \& Co. Ltd. v. Weldon (No. 1), [1990] Ch. 48, [1989] 2 W.L.R. 276 (C.A.), the Court of Appeal accepted an undertaking by plaintiffs that before they applied to a foreign court to enforce the order, they would first seek leave from the English court, which would presumably consider the law of the foreign country in question before granting or denying leave.

49. For a more detailed discussion of this scenario, in the context of a divorce action brought by the wife in England against a husband domiciled in Spain but with assets in the United States, see Andreas F. Lowenfeld, Injunctions Across National Frontiers: A Tale of Two Cities, 3 AM. REV. INT'L ARB. 3 (1993).

50. Felixstowe Dock and Railway Co. v. United States Lines Inc., [1989] 1 Q.B. 360.

51. Cunard Steamship Co. v. Salen Reefer Services AB, 773 F.2d 452 (2d Cir. 1985); see also Victrix Steamship Co., S.A. v. Salen Dry Cargo A.B., 825 F.2d 709 (2d Cir. 1987).

52. It is worth noting that in recent proceedings arising out of the collapse of the Robert Maxwell group of companies, the English and U.S. courts have been cooperating closely. Efforts by individual English creditors to invoke English law against U.S. rules designed to reverse preferential payments shortly before the bankruptcy filing were rejected by the English courts. See Barclays Bank Plc. v. Homan, [1993] BCLC 680 (C.A.). Efforts by the English administration to file an ancillary petition in the U.S. bankruptcy court and to take discovery of persons in the United States from persons having knowledge of U.S. assets of the English debtor were upheld. Petition of Brierly, 145 B.R. 151 (Bankr. S.D.N.Y. 1992). 
new Hague Convention on the Recognition and Enforcement of Judgments could at least endorse an article that said:

(a) nothing in this Convention precludes any contracting party from recognizing injunctions issued by the courts of other states; and

(b) the contracting states commit themselves within [a stated period] to consider the conditions under which orders of courts of other contracting states enjoining the transfer of funds or the bringing of claims against bankrupt estates shall be recognized in other contracting states.

If one needed a precedent for such a provision, one could recall that the drafters of the Brussels Convention were not quite ready to commit their states to submitting decisions on jurisdiction and judgments to review by the European Court of Justice; they issued a Joint Declaration, however, stating that they were "ready ... to examine the possibility ... and if necessary, to negotiate an agreement to this effect." 53 Within three years, they had agreed on a Protocol that indeed did confer jurisdiction on the Court of Justice, thus greatly strengthening the Brussels Convention and its purpose of serving as a unifying force in the European Community.

\section{E. Scope of the Convention}

Finally, what controversies should be excluded from the convention? The Hague Conventions-Service, Evidence, and Judgments (1971)-all focus on "civil and commercial" or "civil or commercial," as do the Brussels and Lugano Conventions. 54 The definition of "civil and commercial" is not clear, and it took the English courts more than three years, two appeals, and finally a decision of the House of Lords before they got it right, in the context of the Hague Evidence Convention. ${ }^{55}$ It is still not clear, however, whether "civil and commercial" should be judged by the law of the state of origin, by the law of the requested state, by the law of both states, or in an autonomous manner, as the Special Commission to review the Operation of the Hague Conventions recommended. ${ }^{56}$

I would urge that the drafters of the proposed judgments convention abandon the term "civil or commercial," or define the term simply by excluding criminal matters, arbitral awards, and matters relating to status. I do not believe there is justification for excluding final judgments relating to succession, or bankruptcy, or, indeed, judgments of administrative tribunals rendered in

53. Joint Declaration attached to EEC Convention, supra note 3.

54. The U.N. Arbitration Convention has no such limitation, but permits states to declare that they will apply it only to differences considered commercial under their national law. About half the contracting states, including the United States and France, but not the United Kingdom, Germany, or Japan, have made this declaration.

55. Re State of Norway's Applications (Nos. 1 and 2), [1990] A.C. 723, [1989] 1 All E.R. 746.

56. See Report on the work of the Special Commission of April 1989 on the operation of the Hague Conventions, 28 I.L.M. 1558, 1563 (1989). 
circumstances assuring fairness and independent decision. ${ }^{57}$ Courts in the United States have recognized judgments in all these areas, without serious threat to the Republic. ${ }^{58}$

In 1973 a U.S. district court appointed a receiver to marshal what was left of the assets of the I.O.S. group of companies that had been systematically looted by the financier Robert Vesco, by then a fugitive. The receiver applied to the English Chancery Court for an order restraining removal from London banks of assets believed to be under Vesco's control, but the English court refused the application, inter alia, on the ground that the receiver was a "public official" seeking to enforce a "penal statute" of the United States-the Securities Exchange Act of $1934 .^{59}$ I think that case is wrongly decided; it does nothing for the sovereignty of the United Kingdom, and only helps crooks to succeed in fleecing clients who once trusted them. I would hope a new judgments convention would correct this injustice. ${ }^{60}$

Again, I would suggest proceeding by stages, that is by including a somewhat narrower scope of coverage of the convention at the first stage, but-rather than excluding the subjects on which agreement is not thought to be attainable at the outset-stating that nothing precludes recognition and enforcement of judgments in situations where recognition is not required, and committing the parties to reconsideration of the scope of the convention within a stated period-say three to five years after the first-stage convention enters into effect.

\section{IV}

\section{CONCLUSION}

This completes my catalogue of proposals for a useful and creative multilateral judgments convention. I believe a convention along the lines of my suggestions would justify the energy and dedication required to achieve any treaty in the field of law, whether negotiated under the auspices of the Hague Conference, UNCITRAL, UNIDROIT, or any other forum. I do not believe a convention drawn too narrowly, or negotiated like a trade agreement, where every benefit is treated like a concession to be paid for by one's negotiating partners, would justify such an effort.

57. Thus, I think that Article 1 of the skeleton draft referred to by Professor von Mehren's article is much too restrictive. von Mehren, supra note 1, at 272.

58. See, e.g., Clarkson Co. Ltd. v. Shaheen, 544 F.2d 624 (2d Cir. 1976) (rights of foreign trustee in bankruptcy to records in United States); Pioneer Cafeteria Feeds, Ltd. v. Mack, 340 F.2d 719 (6th Cir. 1965); Leo Feist, Inc. v. Debmar Publishing Co., 232 F. Supp. 623 (E.D. Pa. 1964) (alleged breach of copyright); In re Aktiebolaget Kreuger \& Toll, 20 F. Supp. 964 (S.D.N.Y. 1937), affirmed, 96 F.2d 768 (2d Cir. 1938) (claims recognized or denied by foreign bankruptcy court); Watts v. Swiss Bank Corp., 265 N.E.2d 739 (N.Y. 1970) (succession to property of decedent); Bullen v. Her Majesty's Government, 553 So. 2d 1344 (Fla. Dist. Ct. App. 1989) (enforcement of order of English court for amounts owed after defendant's conviction for fraudulent evasion of value added tax).

59. Schemmer v. Property Resources Ltd., [1975] Ch. 273, [1974] 3 W.L.R. 406.

60. A recent decision of a Florida court came out the other way, that is, it did recognize the authority of a receiver appointed in a foreign state and ordered by the court of that state to enforce an injunction against dealing with the assets of a debtor company. Belle Island Inv. Co. Ltd. v. Feingold, 453 So. 2d 1143 (Fla. Dist. Ct. App. 1984). 
I believe the supposed nightmare that a judgment will be rendered against an American defendant in a member state of the European Community on an exorbitant basis of jurisdiction and then enforced against assets of the defendant in another member state of the Community ${ }^{61}$ is not adequate justification for entering into a judgments convention, whether bilateral or multilateral. We have seen no such cases in the twenty years since the Brussels Convention entered into effect, and it is unlikely that we will see such cases-or at any rate many such cases-in the future.

What would justify the required effort would be a genuine commitment to the principle that civil controversies that cannot be settled by negotiation or arbitration should be submitted to appropriate courts-but only once. If this objective can be attained, I believe the symbolism will not be lost that the world's democracies respect each other's judicial systems and have a shared perception of essential fairness. Beyond the many technical issues I have tried to raise here, such a message, focused on settlement of disputes, is worth a good deal.

61. See, e.g., Beverly May Carl, The Common Market Judgments Convention-Its Threat and Challenge to Americans, 8 INT'L LAWYER 446 (1974); see also von Mehren, supra note 1. 
$\therefore$ 